\title{
Tensidols, New Potentiators of Antifungal Miconazole Activity, Produced by Aspergillus niger FKI-2342
}

\author{
Takashi Fukuda, Yoko Hasegawa, Keiichi Hagimori, Yuichi Yamaguchi, \\ Rokuro Masuma, Hiroshi Tomoda, Satoshi Ōmura
}

Dedicated to the memory of Professor Kenneth L. Rinehart.

Received: June 2, 2006 / Accepted: August 7, 2006

(C) Japan Antibiotics Research Association

\begin{abstract}
Two new furopyrrols, designated tensidols $\mathrm{A}$ and B, were isolated from the culture broth of Aspergillus niger FKI-2342 by solvent extraction, silica gel column chromatography and HPLC. Their structures were elucidated and shown to have the common skeleton of 6-benzyl-6H-furo[2,3-b]pyrrole. Tensidols A and B potentiated miconazole activity against Candida albicans. Tensidols also showed moderate antimicrobial activity only against Pyricularia oryzae.
\end{abstract}

Keywords tensidol, miconazole potentiator, Aspergillus niger, furopyrrol, fungal metabolite, Candida albicans

\section{Introduction}

Opportunistic infections caused by certain fungi, in particular problematic Candida albicans, have increased to the point of public concern. Patients with compromised immune systems, e.g. patients receiving organ transplants and cancer chemotherapy, or those infected by human immunodeficiency virus, are particularly prone to such infections [1]. We reported actofunicone [2], beauvericins [3], phenatic acids [4] and citridones [5], produced by fungal or actinomycete strains, as potentiators of miconazole activity against $C$. albicans. During the course of our screening program, new compounds, designated tensidols A and B (Fig. 1), were isolated from the culture broth of Aspergillus niger FKI-2342. Both compounds were found to potentiate miconazole activity against $C$. albicans.

In this study, we describe the taxonomy of the producing fungus, fermentation, isolation, structure elucidation and biological properties of tensidols.

\section{Materials and Methods}

\section{General Experimental Procedures}

The strain FKI-2342 was isolated from soil collected at Ooura Tensyudou, Nagasaki, Japan, and was used for production of tensidols. C. albicans ATCC64548 was purchased from ATCC (Virginia, USA). Packed cell volume (PCV) was measured after the whole culture broth $(10 \mathrm{ml})$ was centrifuged at $3000 \mathrm{rpm}$ for 10 minutes. The $\mathrm{pH}$ of the culture broth was measured by using a compact pH meter (Horiba, Kyoto, Japan).

Optical rotations were recorded with a DIP-370 digital polarimeter (Jasco, Tokyo, Japan). FAB-MS spectrometry was conducted on a JMS-AX505H spectrometer (Jeol, Tokyo, Japan). UV and IR spectra were measured with a DU640 spectrophotometer (Beckman, California, USA)
H. Tomoda (Corresponding author): School of Pharmacy, Kitasato University, 5-9-1 Shirokane, Minato-ku, Tokyo 1088641, Japan, E-mail: tomodah@pharm.kitasato-u.ac.jp

Y. Yamaguchi, S. Ōmura: The Kitasato Institute, 5-9-1 Shirokane, Minato-ku, Tokyo 108-8642, Japan
T. Fukuda, Y. Hasegawa, K. Hagimori, R. Masuma: Kitasato Institute for Life Sciences \& Graduate School of Infection Control Sciences, Kitasato University, 5-9-1 Shirokane, Minato-ku, Tokyo 108-8641, Japan 
<smiles>Oc1coc2c1c(O)cn2Cc1ccccc1</smiles>

Tensidol A<smiles>CC(CC(=O)Oc1cn(Cc2ccccc2)c2occ(O)c12)C(=O)O</smiles>

Tensidol B

Fig. 1 Structures of tensidols A and B.

and an FT-210 Fourier transform infrared spectrometer (Horiba, Kyoto, Japan), respectively. The various NMR spectra were measured with a MERCURY plus $300 \mathrm{MHz}$ spectrometer (Varian, California, USA).

\section{Taxonomic Studies of the Producing Organism}

Taxonomic studies and identification were conducted according to the procedures described by Klich [6]. For the taxonomic studies of fungus, Czapeck yeast extract agar (CYA), malt extract agar (MEA) and Czapeck yeast extract agar with 20\% sucrose (CY20S) were used. Morphology was observed under a light microscope (Olympus Vanox-S AH-2) and a scanning electron microscope (JEOL JSM5600). Color names and hue numbers were determined according to the Color Harmony Manual [7].

\section{Assay for Miconazole-potentiating Activity}

The miconazole-potentiating activity of tensidols was tested by paper disk method previously reported by Arai et al. [2]. C. albicans ATCC 64548 was used as a test organism.

\section{Antimicrobial Activity}

Antimicrobial activity against 14 species of microorganisms was measured by our established method [4] using Bacillus subtilis PCI 219, Staphylococcus aureus FDA 209P, Micrococcus luteus PCI 1001, Mycobacterium smegmatis ATCC 607, Escherichia coli NIHJ, Pseudomonas aeruginosa P-3, Xanthomonas campestris pv. Oryzae KB 88, Bacteroides fragilis ATCC 23745, Acholeplasma laidlawii PG 8, Pyricularia oryzae KF 180, Aspergillus niger ATCC 6275, Mucor racemosus IFO 4581, C. albicans ATCC 64548 and Saccharomyces cerevisiae. The following media were employed: GAM agar (Nissui Seiyaku Co., Tokyo, Japan) for Bacteroides fragilis; Bacto PPLO agar (Sanko Junyaku Co. Ltd., Tokyo, Japan) supplemented with $15 \%$ horse serum, $0.1 \%$ glucose, $0.25 \%$ phenol red $(5 \mathrm{mg} / \mathrm{ml})$ and $1.5 \%$ agar for A. laidlawii; Taiyo agar (Shimizu Syokuhin Kaisya Ltd., Shizuoka, Japan) for the other bacteria; a medium composed of $1.0 \%$ glucose, $0.5 \%$ yeast extract and $0.8 \%$ agar for fungi and yeasts. A paper disk (i.d. $6 \mathrm{~mm}$,
Toyo Roshi Kaisha Ltd., Tokyo, Japan) containing $10 \mu \mathrm{g}$ of a sample was placed on an agar plate. Bacteria, with the exception of $X$. oryzae, were incubated at $37^{\circ} \mathrm{C}$ for 24 hours. Yeasts and $X$. oryzae were incubated at $27^{\circ} \mathrm{C}$ for 24 hours. Fungi were incubated at $27^{\circ} \mathrm{C}$ for 48 hours. Antimicrobial activity was expressed as diameter $(\mathrm{mm})$ of the inhibitory zone.

\section{Results}

\section{Taxonomy of the Producing Strain FKI-2342}

Colonies on CYA were $62 \sim 65 \mathrm{~mm}$ diameter after 7 days at $25^{\circ} \mathrm{C}$, velutinous to farinaceous, ebony ( 2 po) to dark brown $(3 \mathrm{pn})$ in color. The reverse side was pale yellow $(1 \mathrm{ca})$ to pale lemon yellow (2 ea). Colonies on MEA were $42 \sim 45 \mathrm{~mm}$ diameter, velutinous to farinaceous, ebony ( 2 po) to dark brown ( $3 \mathrm{pn}$ ) in color. The reverse side was pale yellow (1 ca) to olive gray (1 ig). Colonies on CY20S were $70 \sim 72 \mathrm{~mm}$ diameter, velutinous to farinaceous, ebony ( 2 po to 3 po) in color. The reverse side was pale yellow ( $1 \mathrm{ca}$ ) to pale lemon yellow $(2 \mathrm{ea})$. Conidiogenesis on each medium was abundant. This strain was able to grow on CYA at $37^{\circ} \mathrm{C}, 65 \mathrm{~mm}$ diameter after 7 days. At $5^{\circ} \mathrm{C}$, no colonies were formed on CYA. Conidial structures were consisted of conidiophores, vesicles with biseriate aspergilla. Conidiophores were arised from foot cells and $1000 \sim 2000 \mu \mathrm{m}$ long. They were smooth-walled and hyaline to slightly yellowish brown. Vesicles were globose and $32 \sim 50 \mu \mathrm{m}$ in diameter. Biseriate aspergilla were formed metulae and phialides; metulae were covering the entire surface of the vesicle, cylindrical and $7 \sim 9 \times$ $3.5 \sim 5 \mu \mathrm{m}$ in size with 2 to 4 phialides, phialides were

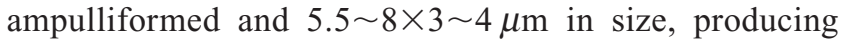
long chains of conida. Conidia were globose to subglobose with finely roughened-wall and $3 \sim 4 \times 3 \sim 4$ (av. 3.4×3.7) $\mu \mathrm{m}$ in size (Fig. 2). This strain can grow at the temperature range from 14 to $43.5^{\circ} \mathrm{C}$ and has the optimum growth range at 24 to $41^{\circ} \mathrm{C}$.

From the above characteristics, strain FKI-2342 was 


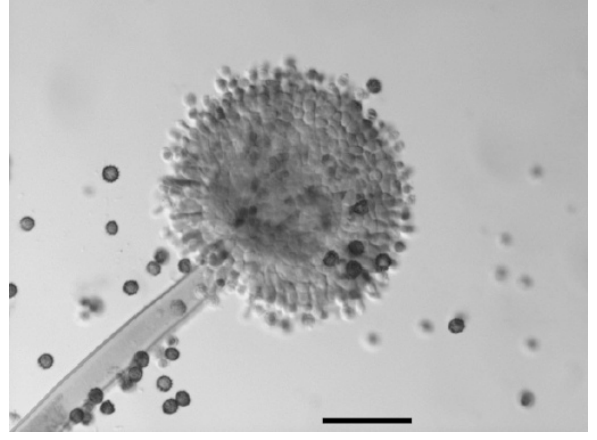

Fig. 2 Aspergillus niger FKI-2342 on CYA.

Scale bar: $20 \mu \mathrm{m}$.

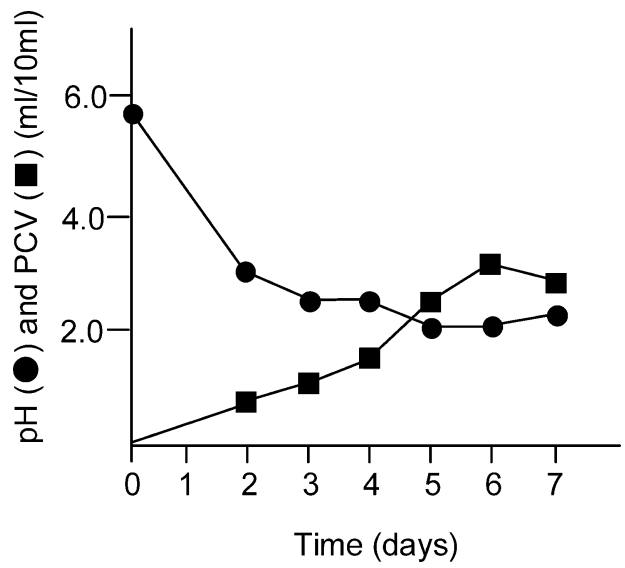

Fig. 3 A typical time course of $\operatorname{PCV}(\boldsymbol{\square})$ and $\mathrm{pH}(\boldsymbol{O})$ in culture broths by $A$. niger FKI-2342.

identified as the genus Aspergillus niger.

\section{Fermentation}

A slant culture of the strain FKI-2342 grown on LcA medium (glycerol $0.1 \%, \mathrm{KH}_{2} \mathrm{PO}_{4} 0.08 \%, \mathrm{~K}_{2} \mathrm{HPO}_{4} 0.02 \%$, $\mathrm{MgSO}_{4} \cdot 7 \mathrm{H}_{2} \mathrm{O} 0.02 \%, \mathrm{KCl} 0.02 \%, \mathrm{NaNO}_{3} 0.2 \%$, yeast extract $0.02 \%$ and agar $1.5 \%, \mathrm{pH} 6.0$ ) was used to inoculate $100 \mathrm{ml}$ of the seed medium (glucose $2.0 \%$, yeast extract $0.2 \%, \mathrm{MgSO}_{4} \cdot 7 \mathrm{H}_{2} \mathrm{O} 0.05 \%$, polypepton $0.5 \%, \mathrm{KH}_{2} \mathrm{PO}_{4}$ $0.1 \%$ and agar $0.1 \%, \mathrm{pH} 6.0$ ) contained in a $500-\mathrm{ml}$ Erlenmeyer flask. The flask was shaken on a rotary shaker at $27^{\circ} \mathrm{C}$ for 3 days. One $\mathrm{ml}$ of the seed culture was incubated with $100 \mathrm{ml}$ of the production medium (glycerol $3.0 \%$, oat meal $2.0 \%$, dry yeast $1.0 \%, \mathrm{KH}_{2} \mathrm{PO}_{4} 1.0 \%$, $\mathrm{Na}_{2} \mathrm{PO}_{4} 1.0 \%, \mathrm{MgCl}_{2} \cdot 6 \mathrm{H}_{2} \mathrm{O} 0.5 \%$ ) contained in a $500-\mathrm{ml}$ Erlenmeyer flask. The fermentation was carried out at $27^{\circ} \mathrm{C}$ for 7 days. A typical time course of the fermentation is shown in Fig. 3. The $\mathrm{pH}$ value changed from 5.8 to 2.0 on day 5 and PCV was increased gradually up to day 6 .

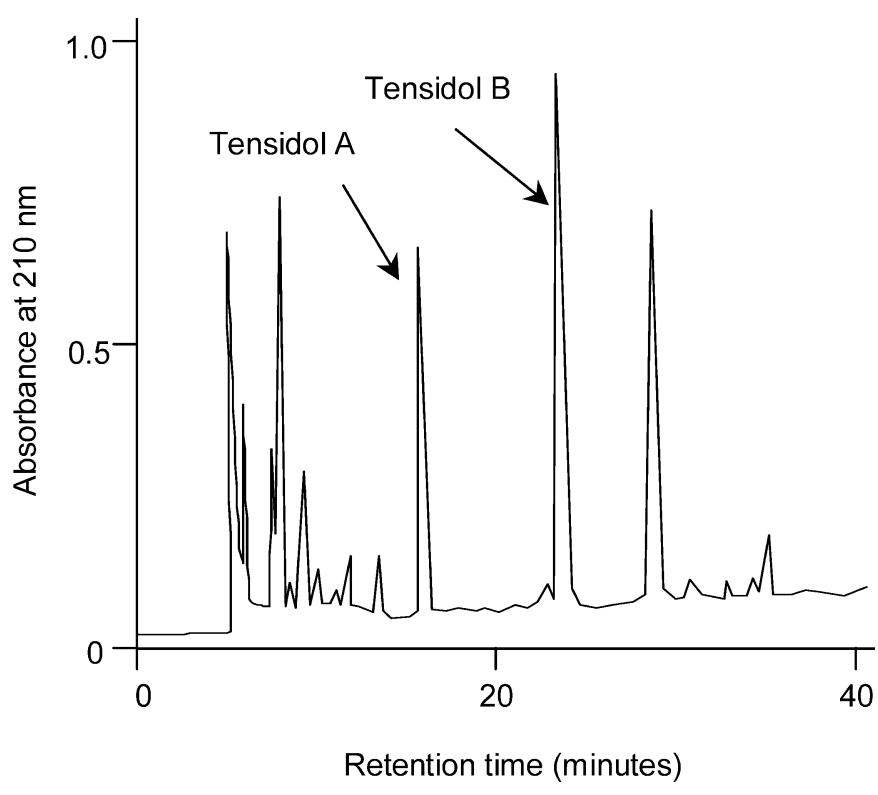

Fig. 4 A chromatographic profile of purification of tensidols $A$ and $B$ by preparative HPLC.

Column, Senshu Pak PEGASIL ODS $(20 \times 250 \mathrm{~mm})$; solvent, 40-minute linear gradient from 30 to $50 \% \mathrm{CH}_{3} \mathrm{CN}$ in $0.05 \% \mathrm{H}_{3} \mathrm{PO}_{4}$; detection, UV at $210 \mathrm{~nm}$; flow rate, $8.0 \mathrm{ml} /$ minute; sample, $10 \mu \mathrm{g}$ of active materials dissolved in $10 \mu \mathrm{l}$ of $\mathrm{MeOH}$.

\section{Isolation}

To the 7-day old culture broth (1.4 liter) was added acetone (1.4 liter). After the acetone extracts were filtered and concentrated, the resulting aqueous solution was extracted with ethyl acetate (1.4 liter). The ethyl acetate layer was dried over $\mathrm{Na}_{2} \mathrm{SO}_{4}$ and concentrated in vacuo to dryness to yield an oily material $(1.33 \mathrm{~g})$. The material was dissolved in a small volume of $\mathrm{CHCl}_{3}$, applied on a silica gel column $(50 \mathrm{~g}, 3.0 \times 15 \mathrm{~cm}, 70 \sim 230$ mesh, Merck), and eluted stepwise with $100: 0,100: 1,50: 1,10: 1$ and $0: 100(\mathrm{v} / \mathrm{v})$ of $\mathrm{CHCl}_{3}-\mathrm{CH}_{3} \mathrm{OH}(500 \mathrm{ml}$ each). The miconazolepotentiating activity was observed in the fraction, eluted with the 50:1 solvent mixture, which was concentrated to give a brown material $(79.1 \mathrm{mg})$. The material was purified by HPLC; ODS column $(20 \times 250 \mathrm{~mm}$, Pegasil, Senshu Sci. Co. Tokyo, Japan), a 40-minutes linear gradient from 30 to $50 \% \mathrm{CH}_{3} \mathrm{CN}$ in $0.05 \% \mathrm{H}_{3} \mathrm{PO}_{4}, 8.0 \mathrm{ml} /$ minute, and $\mathrm{UV}$ at $210 \mathrm{~nm}$. Under the conditions, tensidols $\mathrm{A}$ and $\mathrm{B}$ were eluted as peaks with retention times of 16.0 and 23.5 minutes, respectively (Fig. 4). Each fraction was collected and extracted with ethyl acetate to yield tensidols A $(1.2 \mathrm{mg})$ and $\mathrm{B}(2.6 \mathrm{mg})$ as yellow powder. 
Table 1 Physico-chemical properties of tensidols A and B

\begin{tabular}{|c|c|c|}
\hline & Tensidol A & Tensidol B \\
\hline Appearance & yellow powder & yellow powder \\
\hline$[\alpha]_{D}^{25}$ & $+27.6\left(\mathrm{c} 0.1, \mathrm{CH}_{3} \mathrm{OH}\right)$ & $+3.7\left(c 0.1, \mathrm{CH}_{3} \mathrm{OH}\right)$ \\
\hline Molecular formula & $\mathrm{C}_{13} \mathrm{H}_{11} \mathrm{NO}_{3}$ & $\mathrm{C}_{18} \mathrm{H}_{17} \mathrm{NO}_{6}$ \\
\hline Molecular weight & 229 & 343 \\
\hline \multicolumn{3}{|c|}{ HR-FAB-MS $m / z(M+H)^{+}$} \\
\hline Calcd & 230.0817 (for $\mathrm{C}_{13} \mathrm{H}_{12} \mathrm{NO}_{3}$ ) & 344.1134 (for $\mathrm{C}_{18} \mathrm{H}_{18} \mathrm{NO}_{6}$ ) \\
\hline Found & 230.0813 & 344.1056 \\
\hline$\cup V \lambda_{\max }^{\mathrm{CH}_{3} \mathrm{OH}} \mathrm{nm}(\varepsilon)$ & $206(13,700), 250(4,100)$ & $206(25,000), 243(11,000)$ \\
\hline $\mathrm{IR} v_{\max }^{\mathrm{KBr}} \mathrm{cm}^{-1}$ & $3360,1683,1668$ & $3530,3360,1697,1683,1670$ \\
\hline \multicolumn{3}{|l|}{ Solubility } \\
\hline Soluble & $\mathrm{CH}_{3} \mathrm{OH}, \mathrm{CHCl}_{3}, \mathrm{EtOAc}$ & $\mathrm{CH}_{3} \mathrm{OH}, \mathrm{CHCl}_{3}, \mathrm{EtOAc}$ \\
\hline Insoluble & $\mathrm{H}_{2} \mathrm{O}$ & $\mathrm{H}_{2} \mathrm{O}$ \\
\hline
\end{tabular}

\section{Structure Elucidation}

Physico-chemical Properties of Tensidols

Physico-chemical properties of tensidols $\mathrm{A}$ and $\mathrm{B}$ are summarized in Table 1. Tensidols A and B showed similar absorption at 206 and $243 \sim 250 \mathrm{~nm}$. Tensidol A showed absorption at $3360 \mathrm{~cm}^{-1}$, suggesting the presence of hydroxyl groups. Tensidol B showed the absorption at 3530 and $3360 \mathrm{~cm}^{-1}$, suggesting the presence of carboxylic acid and hydroxyl groups. Similarity of their spectral data indicated close structural relationships.

Tensidol A

The molecular formula of tensidol A was determined to be $\mathrm{C}_{13} \mathrm{H}_{11} \mathrm{NO}_{3}$ on the basis of HRFAB-MS measurement (Table 1). The ${ }^{13} \mathrm{C}$ NMR spectrum (in $\mathrm{CDCl}_{3}$ ) showed 13 resolved signals, which were classified into one methylene carbon, seven $s p^{2}$ methine carbons and three quaternary carbons by analysis of DEPT spectra. The ${ }^{1} \mathrm{H}$ NMR spectrum (in $\mathrm{CDCl}_{3}$ ) showed one methylene signal, two methine signals and five aromatic signals. The connectivity of proton and carbon atoms was established by the ${ }^{13} \mathrm{C}-{ }^{1} \mathrm{H}$ HMQC spectrum as shown in Table 2. Analysis of the ${ }^{1} \mathrm{H}-$ ${ }^{1} \mathrm{H}$ COSY and ${ }^{13} \mathrm{C}-{ }^{1} \mathrm{H}$ HMBC spectra revealed the two partial structures I and II (Fig. 5). The ${ }^{13} \mathrm{C}-{ }^{1} \mathrm{H}$ long range couplings of ${ }^{2} J$ and ${ }^{3} J$ observed in the HMBC experiments (Fig. 5) gave the following information. The cross peaks from $7-\mathrm{H}_{2}(\delta 3.90)$ to $\mathrm{C}-8(\delta 133.7)$ and $\mathrm{C}-9(\delta$ $129.1)$ and from $9-\mathrm{H}(\delta 7.25)$ to $\mathrm{C}-7$ ( $\delta 39.6)$ supported the partial structure I. The cross peaks from $2-\mathrm{H}(\delta 8.75)$ to $\mathrm{C}-$ $3(\delta 178.0), \mathrm{C}-3 \mathrm{a}(\delta 119.1)$ and C-6a $(\delta 168.8)$ and from $5-$ $\mathrm{H}(\delta$ 6.25) to C-3a, C-4 ( $\delta$ 164.3) and C-6a supported the partial structure II. The cross peaks from $5-\mathrm{H}$ to $\mathrm{C}-7$ and from 7-H to C-6a and C-5 indicated that the partial structures I and II are linked at a nitrogen as shown in Fig. 5. The structure satisfied the molecular formula and degree of unsaturated.

Taken together, the structure of tensidol A was elucidated as shown in Fig. 1.

\section{Tensidol B}

The molecular formula of tensidol $\mathrm{B}\left(\mathrm{C}_{18} \mathrm{H}_{17} \mathrm{NO}_{6}\right)$ is larger by $\mathrm{C}_{5} \mathrm{H}_{6} \mathrm{O}_{3}$ when compared with tensidol $\mathrm{A}$. The difference between tensidols $\mathrm{A}$ and $\mathrm{B}$ is the presence of the partial structure III for tensidol B (Fig. 3), which was elucidated by the ${ }^{1} \mathrm{H}-{ }^{1} \mathrm{H}$ COSY and HMBC spectra. The cross peaks from $2^{\prime}-\mathrm{H}_{2}(\delta 2.92,3.28)$ to $\mathrm{C}-1^{\prime}(\delta 172.8), \mathrm{C}-3^{\prime}(\delta$ $34.4), \mathrm{C}-4^{\prime}(\delta 177.7)$ and $\mathrm{C}-5^{\prime}(\delta 17.3)$, from $3^{\prime}-\mathrm{H}(\delta 3.07)$ to $\mathrm{C}-1^{\prime}, \mathrm{C}-2^{\prime}, \mathrm{C}-4^{\prime}$ and $\mathrm{C}-5^{\prime}$ and from $5^{\prime}-\mathrm{H}(\delta 1.30)$ to $\mathrm{C}-$ $2^{\prime}, \mathrm{C}-3^{\prime}$ and $\mathrm{C}-4^{\prime}$ were observed in the ${ }^{13} \mathrm{C}-{ }^{1} \mathrm{H}$ HMBC experiments to comfort the partial structure III (Fig. 6). Because the chemical shift of C-4 $(\delta$ 161.2) moved to the higher field in comparison with that of tensidol A ( $\delta$ 164.3), the partial structure III is linked to C-4 via an oxygen as shown in Fig. 1. The structure satisfied the molecular formula and the unsaturated degree (Table 1). Thus, the structure of tensidol B was elucidated as shown in Fig. 1.

\section{Biological Properties}

Miconazole-potentiating Activity

The miconazole-potentiating activity of tensidols was tested. Tensidols A and B showed no inhibition zone against wild C. albicans even at $50 \mu \mathrm{g} /$ disk on Plate A (GY agar). However, tensidols $\mathrm{A}$ and $\mathrm{B}$ gave dose-dependent 
Table $2{ }^{1} \mathrm{H}$ and ${ }^{13} \mathrm{C}$ NMR chemical shifts of tensidols $\mathrm{A}$ and $\mathrm{B}$

\begin{tabular}{|c|c|c|c|c|}
\hline & \multicolumn{2}{|c|}{ Tensidol A } & \multicolumn{2}{|c|}{ Tensidol B } \\
\hline & $\begin{array}{l}{ }^{13} \mathrm{C} \text { chemical } \\
\text { shifts (ppm) }{ }^{a}\end{array}$ & $\begin{array}{l}{ }^{1} \mathrm{H} \text { chemical } \\
\text { shifts }(\mathrm{ppm})^{\mathrm{b}}\end{array}$ & $\begin{array}{l}{ }^{13} \mathrm{C} \text { chemical } \\
\text { shifts (ppm) }{ }^{a}\end{array}$ & $\begin{array}{l}{ }^{1} \mathrm{H} \text { chemical } \\
\text { shifts }(\mathrm{ppm})^{\mathrm{b}}\end{array}$ \\
\hline $\mathrm{C}-2$ & 162.0 & $8.75(1 \mathrm{H}, \mathrm{s})$ & 163.1 & $8.74(1 \mathrm{H}, \mathrm{s})$ \\
\hline C-3 & 178.0 & & 177.7 & \\
\hline C-3a & 119.1 & & 119.8 & \\
\hline C-4 & 164.3 & & 161.2 & \\
\hline C-5 & 116.0 & $6.25(1 \mathrm{H}, \mathrm{s})$ & 116.2 & $6.30(1 \mathrm{H}, \mathrm{s})$ \\
\hline C-6a & 168.8 & & 169.3 & \\
\hline $\mathrm{C}-7$ & 39.6 & $3.90(2 \mathrm{H}, \mathrm{s})$ & 39.6 & $3.90(2 \mathrm{H}, \mathrm{s})$ \\
\hline C-8 & 133.7 & & 133.6 & \\
\hline C-9 & 129.1 & $7.29(2 \mathrm{H}, \mathrm{m})$ & 129.1 & $7.36(2 \mathrm{H}, \mathrm{m})$ \\
\hline C-10 & 127.8 & $7.25(2 \mathrm{H}, \mathrm{m})$ & 128.0 & $7.24(2 \mathrm{H}, \mathrm{m})$ \\
\hline $\mathrm{C}-11$ & 129.1 & $7.29(1 \mathrm{H}, \mathrm{m})$ & 129.1 & $7.36(1 \mathrm{H}, \mathrm{m})$ \\
\hline $\mathrm{C}-1^{\prime}$ & & & 172.8 & \\
\hline \multirow[t]{2}{*}{ C-2' } & & & 41.8 & $2.92(1 \mathrm{H}, \mathrm{dd}, J=8.5,5.0)$ \\
\hline & & & & $3.28(1 \mathrm{H}, \mathrm{dd}, J=8.5,5.0)$ \\
\hline C-3' & & & 34.4 & $3.07(1 \mathrm{H}, \mathrm{m})$ \\
\hline $\mathrm{C}-4^{\prime}$ & & & 177.7 & \\
\hline$C-5^{\prime}$ & & & 17.3 & $1.30(3 \mathrm{H}, \mathrm{d}, J=7.5)$ \\
\hline $3-\mathrm{OH}$ & & $5.90(1 \mathrm{H}, \mathrm{brs})^{\mathrm{c}}$ & & $11.79(1 \mathrm{H}, \mathrm{s})$ \\
\hline $4-\mathrm{OH}$ & & $9.05(1 \mathrm{H}, \mathrm{br} \mathrm{s})^{\mathrm{c}}$ & & \\
\hline
\end{tabular}

${ }^{a}$ Chemical shifts are shown with reference to $\mathrm{CDCl}_{3}$ as $77.0 \mathrm{ppm}$.

${ }^{b}$ Chemical shifts are shown with reference to $\mathrm{CDCl}_{3}$ as $7.26 \mathrm{ppm}$.

${ }^{\mathrm{c}}$ The assigments may be exchangeable.

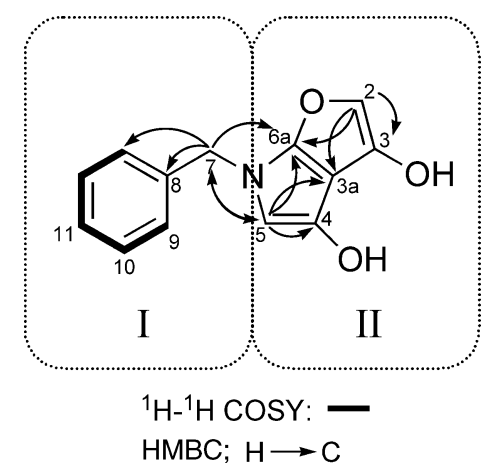

Fig. 5 Partial structures | and || and key cross peaks observed in ${ }^{1} \mathrm{H}-{ }^{1} \mathrm{H}$ COSY and $\mathrm{HMBC}$ experiments of tensidol A.

inhibition zones on Plate B (Plate A containing miconazole $(0.06 \mu \mathrm{M}))$ (Table 3). These results indicated that tensidols $\mathrm{A}$ and $\mathrm{B}$ potentiate miconazole activity against $C$. albicans.

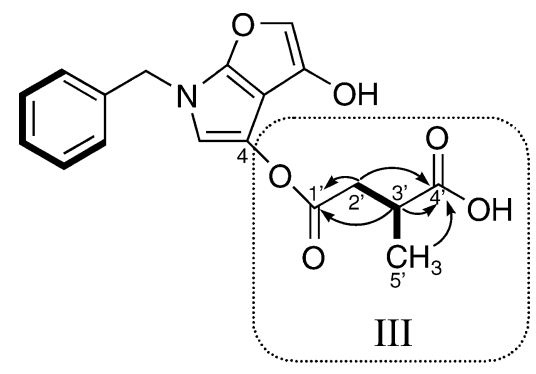

${ }^{1} \mathrm{H}-{ }^{1} \mathrm{H}$ COSY:

HMBC: $\mathrm{H} \rightarrow \mathrm{C}$
Fig. 6 Partial structure III and key cross peaks observed in ${ }^{1} \mathrm{H}-{ }^{-1} \mathrm{H}$ COSY and $\mathrm{HMBC}$ experiments of tensidol $\mathrm{B}$.

Antimicrobial Activity

Tensidols A and B showed weak antifungal activity against P. oryzae (inhibition zone at a concentration $10 \mu \mathrm{g} / 6 \mathrm{~mm}$ disk: 13 and $13 \mathrm{~mm}$, respectively), but no activity against the other microorganisms: Bacillus subtilis, S. aureus, M. 
Table 3 Potentiation of micanazole activity against $C$ albicans by tensidols

\begin{tabular}{|c|c|c|c|}
\hline \multirow{2}{*}{ Tensidol } & \multirow{2}{*}{$\begin{array}{c}\text { Concentration } \\
\mu \mathrm{g} / \text { disk }\end{array}$} & \multicolumn{2}{|c|}{ Inhibition zone (mm) } \\
\hline & & Plate A & Plate B \\
\hline \multirow[t]{3}{*}{$A$} & 50 & - & 21 \\
\hline & 25 & - & 19 \\
\hline & 10 & - & 14 \\
\hline \multirow[t]{3}{*}{ B } & 50 & - & 15 \\
\hline & 25 & - & 12 \\
\hline & 10 & - & - \\
\hline
\end{tabular}

Paper disks ( $8 \mathrm{~mm}$ i.d.) containing three concentrations of a compound were put on Plate A (C. albicans in GY agar) and Plate B (C. albicans in $\mathrm{GY}$ agar $+0.06 \mu \mathrm{M}$ miconazole), and incubated at $27^{\circ} \mathrm{C}$. After 24 hours, the diameters of inhibition zones were measured. The concentration $(0.06 \mu \mathrm{M})$ of miconazole is one fourth of the MIC value against $C$. albicans that showed no effect on the growth of $C$. albicans.

luteus, M. smegmatis, E. coli, P. aeruginosa, $X$. campestris, Bacteroides fragilis, A. laidlawii, A. niger, M. racemosus, C. albicans and S. cerevisiae.

\section{Discussion}

As described in this study, tensidols A and B are new potentiators of miconazole activity against $C$. albicans. The potentiating activity of tensidol $\mathrm{A}$ is more potent than that of tensidol B, suggesting that the 2-methyl butanoic acid moiety at the hydroxy group interferes with the activity. Tensidols A and B did not potentiate miconazole activity against fluconazole-resistant $C$. albicans (data not shown). It suggests that tensidols act on the potentiating mechanism other than the efflux pumps, but we need more investigation to define this point. We have reported several miconazolepotentiators such as actofunicone, beauvericins, phenatic acids and citridones. When compared with their potency, tensidols are rather weak potentiators of antifungal miconazole activity.

Tensidols have the unique 6a-dihydro-3a $H$-furo[2,3$b]$ pyrrole skeleton in common, which has not been reported so far. The chemical sifts of C-2 (162.0 and $163.1 \mathrm{ppm})$ and C-3 (178.0 and $177.7 \mathrm{ppm}$ ) of furan ring in tensidols A and $\mathrm{B}$ are much lower than those of usual furan rings (about $110 \sim 140 \mathrm{ppm}$ ), concluding the presence of a 3-hydroxyl furan ring. Regarding the structure of tensidol $\mathrm{B}$, there are four possible ester forms; 3-OH or 4-OH of the furopyrrol ring is bound to $1^{\prime}$ or $4^{\prime}$ carboxylic acid of methylsuccinic acid. We concluded that $4-\mathrm{OH}$ is linked to $1^{\prime}$-carboxylic acid because the chemical shift of C-4 (161.2 ppm) moved to a higher field in comparison with that $(164.3 \mathrm{ppm})$ of tensidol $\mathrm{A}$, and the chemical shift of an ester carbonyl carbon (C-1', $172.8 \mathrm{ppm}$ ) should be in a higher field than that of a hydroxyl carbonyl carbon (C-4', $177.7 \mathrm{ppm})$. Further experiments, e.g., X-ray crystallography or total synthesis, are needed to corroborate this assessment.

Acknowledgments We wish to thank Ms. Noriko Sato, Ms. Akiko Nakagawa and Ms. Chikako Sakabe, School of Pharmacy, Kitasato University, for measurements of NMR and mass spectra. This study was supported by the 21 st Century COE Program and KAKENHI 16073215, Ministry of Education, Culture, Sports, Science and Technology, Japan.

\section{References}

1. Nishiyama Y, Yamaguchi H. Made of action of antifungal agents for treatment of systematic fungal infection. Antibiot Chemother 16: 19-26 (2000)

2. Arai M, Tomoda H, Okuda T, Wang H, Tabata N, Masuma R, Yamaguchi Y, Ōmura S. Funicone-related compounds, potentiators of antifungal miconazole activity, prodused by Talaromyces flavus FKI-0067. J Antibiot 55: 172-180 (2002)

3. Fukuda T, Arai M, Yamaguchi Y, Masma R, Tomoda H, Ōmura S. New beauvericins, potentiators of antifungal miconazole activity, produced by Beauveria sp. FKI-1366. I. Taxonomy, fermentation, isolation, and biological properties. J Antibiot 57: 110-116 (2004)

4. Fukuda T, Mathumoto A, Takahashi Y, Tomoda H, Ōmura S. Phenatic acids $\mathrm{A}$ and $\mathrm{B}$, new potentiators of antifungal miconazole activity produced by Streptomyces sp. K030132. J Antibiot 58: 252-259 (2005)

5. Fukuda T, Yamaguchi Y, Masuma R, Tomoda H, Ōmura S. Citridones, potentiators of antifungal miconazole activity, produced by Penicillium sp. FKI-1938 I. Taxonomy, fermentation, isolation, and biological properties. J Antibiot 58: 309-314 (2005)

6. Klich AM. Identification of Common Aspergillus Species. Centraalbureau voor Schimmelcultures, Utrecht, The Netherlands (2002)

7. Taylor HD, Knoche L, Granville WC. Color Harmony Manual 4th Ed. Container of America, Chicago (1958) 